\title{
Nutritional value of gluten-free rice and bean based cake mix
}

\author{
Priscila Zaczuk Bassinello ${ }^{1^{*}}$ (D) Juliana Aparecida Correia Bento ${ }^{2}$ (D) \\ Luciana de Oliveira Froes Gomes ${ }^{2}$ Márcio Caliari ${ }^{2}$ Bassoodeo Dave Oomah ${ }^{3}$
}

${ }^{1}$ Empresa Brasileira de Pesquisa Agropecuária (Embrapa), Embrapa Arroz e Feijão, 75375-000, Santo Antônio de Goiás, GO, Brasil. E-mail: priscila.bassinello@embrapa.br. "Corresponding author.

${ }^{2}$ Escola de Agronomia, Universidade Federal de Goiás (UFG), Goiânia, GO, Brasil.

${ }^{3}$ Summerland Research and Development Centre, Agriculture and Agri-Food Canada, 4200, Highway 97, Mailbox 5000, Summerland, BC, Canada.

ABSTRACT: Gluten-free foods are a growing trend in the domestic and international markets, contributing to health and wellness, especially the celiac public. The objective of this study was to create a new option of gluten-free food by replacing wheat flour by rice grit flour, cornstarch, and extruded split bean flour, and to aggregate value to low cost industrial byproducts. A new food product was developed and its components analyzed for their nutritional characteristics and changes during baking. The baked cakes can be a source of protein, had a good starch and protein digestibility, and low antinutritional factors, notably tannins. Incorporation of an extruded bean flour in a gluten-free cake mix improves protein digestibility, total dietary fiber, and raises ash, iron, and zinc contents.

Key words: Oryza sativa, Phaseolus vulgaris, starch and protein digestibility, extruded bean flour, antinutritional compounds.

Valor nutricional de mistura de bolo sem glúten a base de arroz e feijão

RESUMO: Os alimentos sem glúten são uma tendência crescente no mercado doméstico e internacional, contribuindo para a saúde e o bem-estar, principalmente do público celíaco. O objetivo deste estudo foi desenvolver novas opções de alimentos sem glúten, substituindo a farinha de trigo por farinha de arroz, amido de milho e farinha de feijão extrusada, agregando assim valor a subprodutos industriais de baixo custo. Um novo produto alimentar foi desenvolvido e seus componentes analisados quanto às suas características nutricionais e alterações durante o cozimento. Os bolos assados podem ser fontes de proteínas, possuem boa digestibilidade de amido e proteinas e baixos fatores antinutricionais, principalmente taninos. A incorporação da farinha de feijão extrusada na mistura para bolos sem glúten melhorou a digestibilidade das proteinas, a fibra alimentar total e aumentou o teor de cinzas, ferro e zinco.

Palavras-chave: Oryza sativa, Phaseolus vulgaris, digestibilidade de amido e proteina, farinha de feijão extrusada, compostos antinutricionais.

\section{INTRODUCTION}

Food sensitivity is one of four micro environmental trends contributing to an increased focus on health and wellness. According to the Nielsen's Global Health and Ingredient - Sentiment Survey of consumers in 63 countries (2016) more than one-third $(36 \%)$ of respondents have an allergy or intolerance to one or more type of food and $70 \%$ actively make dietary choices to prevent health problems such as obesity, diabetes, high cholesterol, and hypertension. The gluten-free products have a high market value and are; therefore, difficult for low- income people to access (LAMBERT \& FICKEN, 2016). However, products specifically marketed as gluten-free are reduced in several sensorial characteristics, are more expensive, and have lower nutritional values than comparable alternatives (XHAKOLLARI et al., 2019). Successful strategies to enter the gluten-free market are the development of novel products by creating a new version of traditional products using alternative ingredients (KAUR et al., 2015, SHEVKANI \& SINGH, 2014, BASSINELLO et al., 2011), such as broken rice and split beans, which are five times cheaper than whole rice and whole beans. Both are under utilized 
by Brazilian industry, despite having a nutritional composition similar to whole grains (CARVALHO et al., 2012, GOMES et al., 2014a).

Common bean (Phaseolus vulgaris L.) is one of the most consumed and important legumes in the world. Beans are sources of protein, carbohydrates, dietary fiber, starch, phenolic compounds, vitamins and minerals (LIMA et al., 2019). So, the use of split beans is a good strategy to hence the nutritional value of gluten-free products. However, beans present antinutritional factors such as phytates (inositol hexaphosphate). Its unique structure determines the ability of phytic acid to chelate with divalent cations of macro- and microelements to form stable and insoluble salts. The literature data provided the negative relationship between phytic acid in the diet and the intestinal absorption of $\mathrm{Ca}, \mathrm{Fe}$ and $\mathrm{Zn}$ (KIEWLICZ et al., 2020). Nevertheless, this antinutritional can be reduced by technological processes such as thermal process and fermentation (DE PASQUALE et al., 2020).

Moreover, a split bean have been extruded to eliminate products related to bean's off-flavor and short shelf-life; besides that, the combination of ingredients that provide the right texture and follows the 'healthy lifestyle' option. For example, extruded split bean flour has high water absorption, benefiting the final product quality (improved moisture retention, firmness, elasticity, texture, and high acceptability) (GOMES et al., 2014b).

Gluten-free cake mix formulations containing broken rice flour and extruded split beans showed storage stability up to eight months at room temperature without affecting technological properties and had good acceptability based on a sensory analysis (LOPES et al., 2012). Extrusion also increases the nutritional value of bean flours by preserving the protein nutritional value, inactivating the trypsin inhibitor $(>85 \%)$ and lectin $(>90 \%)$ activities, increasing in vitro protein digestibility and soluble fiber content (BERRIOS et al., 2013). However, bean extrusion can potentially reduce lysine availability and the expansion index that may lead to undesirable product quality (low cake volume and symmetry) (BATISTA et al., 2010). Therefore, the extrusion of split bean flour is an excellent alternative to reduce/eliminate antinutritional factors and also improves product digestibility and shelflife (CARVALHO et al., 2012a; CARVALHO et al., 2012b, GOMES et al., 2014a; GOMES et al., 2014b, LOPES et al., 2012).

Therefore, the objective of this study was to develop gluten-free cake mixes by replacing wheat flour by extruded split bean flour (EBF), rice grit flour (RGF) and corn starch (CS), and to evaluate the nutritional value of the baked cakes.

\section{MATERIALS AND METHODS}

\section{Flours}

Polished rice grits (Oryza sativa) and split beans (Phaseolus vulgaris) were obtained from the industry and processed in a cyclone-type mill (FOSS, CyclotecTM1093, Höganäs, Sweden) to obtain raw rice and bean flour. The raw bean flour (RBF) was extruded in single-screw extruders (Inbramaq, RXPQ Labor 24, Ribeirão Preto, Brazil). Extrusion conditions: motor speed at $60 \mathrm{~Hz}$; single spiral thread with three heating zones $\left(30,40\right.$ and $70{ }^{\circ} \mathrm{C}$ and $21 \%$ humidity), with the temperature of the last zone being $70{ }^{\circ} \mathrm{C}$; feed rate of $290 \mathrm{~g} \mathrm{~min}^{-1}$. The corn starch (CS) (Unilever ${ }^{\circledR}$, Garanhuns/PE, Brazil) and the wheat flour (WF) (Emegê $\hat{e}^{\circledR}$ - Goiânia/GO, Brazil) were obtained in the local market.

\section{Cake mix preparation and baking}

A complete randomized design was used to evaluate the nutritional contribution after replacing wheat flour (WF) by dry mixtures of RCF (mixtures of $75 \% \mathrm{RGF}$ and $25 \% \mathrm{CS}$ ) and extruded bean flour $(\mathrm{EBF})$ in the cake mix. The control product had $100 \%$ wheat flour named trial cake mix (TCM), and three other treatments were obtained by replacing wheat flour by different proportions of EBF and RCF (45/55\%, 60/40\%, 75/25\%, respectively), according to table 1 (dry ingredients).

The wet ingredients used were obtained in the local market: eggs (165 g) - Josidith ${ }^{\circledR}$, Bela Vista de Goiás/GO, Brazil; margarine (40 g) Qualy $^{\circledR}$, Paranaguá/PR, Brazil; whole milk (150 mL) - Piracanjuba ${ }^{\circledR}$, Piracanjuba/GO, Brazil, which were added to each cake mix equally. All formulations were homogenized in a mixer (Arno Deluxe SX80, Mooca, Brazil), with speed level 4 for 4 min and baked at 180 ${ }^{\circ} \mathrm{C}$, for $35 \mathrm{~min}$ in a pre-heated electric oven (Layr, Luxo $2400 \mathrm{~W} /$ thermo control, Jundiaí, Brazil). The ready-to-eat cakes (control cake or wheat-based cake - WC; cake with $45 \%$ of EBF - C45; cake with $60 \%$ of EBF - C60; cake with $75 \%$ of EBF - C75) were lyophilized before the analyses.

\section{Proximate composition}

Official methods of analyses (AOAC, 2005) were performed to determine total lipids by Soxhlet gravimetric extraction, ash content by furnace incineration at $550{ }^{\circ} \mathrm{C}$, and protein content according 
Table 1 - Dry ingredients percentage used for the cake mix.

\begin{tabular}{|c|c|c|c|c|c|c|}
\hline Cake Mix ${ }^{1}$ & --------------------- & lours-----. & ---------- & & Baking powder $^{6}$ & Salt $^{7}$ \\
\hline & Wheat flour ${ }^{2}$ & $\mathrm{EBF}^{3}$ & $\mathrm{RCF}^{4}$ & Sugar $^{5}$ & & \\
\hline TCM & $37.44 \%$ & - & - & $59.36 \%$ & $2.97 \%$ & $0.23 \%$ \\
\hline CM45 & - & $16.85 \%$ & $20.59 \%$ & $59.36 \%$ & $2.97 \%$ & $0.23 \%$ \\
\hline CM60 & - & $22.46 \%$ & $14.98 \%$ & $59.36 \%$ & $2.97 \%$ & $0.23 \%$ \\
\hline CM75 & - & $28.08 \%$ & $9.36 \%$ & $59.36 \%$ & $2.97 \%$ & $0.23 \%$ \\
\hline
\end{tabular}

${ }^{1} \mathrm{TCM}$ : control cake mix (100\% wheat flour); CM45: cake mix 45\% (45\% EBF + 55\% RCF); CM60: cake mix $60 \%(60 \% \mathrm{EBF}+40 \%$ $\mathrm{RCF})$; CM75: cake mix 75\% $(75 \% \mathrm{EBF}+25 \% \mathrm{RCF}) .{ }^{2}$ Emegê ${ }^{\circledR}$ - Goiânia/GO, Brazil. ${ }^{3} \mathrm{EBF}$ : extruded split beanflour. ${ }^{4} \mathrm{RCF}$ : mixtures of rice grit flour (75\%) and corn starch $(25 \%) .{ }^{5}$ União ${ }^{\circledR}-$ São Paulo/SP, Brazil. ${ }^{6}$ Royal ${ }^{\circledR}$ - Volta Redonda/RJ, Brazil. ${ }^{7}$ Cisne ${ }^{\circledR}$ - Cabo Frio/RJ Brazil.

to the Kjeldahl's method $(\mathrm{N} \times 6.25$ for pulses flour, mixes and cakes; $\mathrm{N}$ x 5.95 for wheat) (AOAC Official Method 960.52). The total dietary fiber fraction (TDF), soluble dietary fiber fraction (SDF), and the insoluble dietary fiber fraction (IDF) were analyzed by the gravimetric-enzymatic method, established by AOAC (2005). Three or four replicates were done for all assays. Total carbohydrates were estimated by difference (Equation 1). The total energy value of the formulated products was estimated using $4 \mathrm{kcal} / \mathrm{g}$ conversion factor for proteins and carbohydrates, and $9 \mathrm{kcal} / \mathrm{g}$ for lipids (MERRIL \& WATT, 1973). Total Carbohydrate $=100$ - Protein - Lipids - Ash - TDF

(Equation 1)

\section{Mineral and vitamin composition}

Minerals were determined according to NOGUEIRA \& SOUZA (2005) where the iron (Fe), calcium $(\mathrm{Ca})$, and zinc $(\mathrm{Zn})$ contents were quantified through atomic absorption spectrophotometry. The thiamine (B1) and riboflavin (B2) vitamins were determined through high-performance liquid chromatography (HPLC - Prominence / Shimadzu Corporation) according to the technique approved by the European Committee for Standardization (2003).

\section{Phytic acid and tannin contents}

The phytic acid content was determined by HAUG \& LANTZSCH'S (1983) method and the tannin content according to the method established by HAGERMAN \& BUTLER (1978).

\section{Amino acids profile}

The amino acids profile was determined according to the method proposed by BRIAN et al. (1984). The separation of feniltiocarbamil-amino acid derivative (PTC-AA) was performed on C18 reverse phase column (Pico-Tag, Waters, $3.9 \times 150$ $\mathrm{mm})$ with monitoring at $254 \mathrm{~nm}$ wavelength. The essential amino acids score (EAS) was estimated from the results of these analyses, according to the World Health Organization, WHO/FAO/UNU guidelines (2007). This analysis was performed with three replicates.

\section{Protein and starch digestibility}

The flours and cakes were evaluated for protein and starch digestibility. The in vitro protein digestibility was evaluated by the multi-enzymatic technique of AKESON \& STAHMANN (1964). The digestibility for casein was set as control (100\%), flours corrected in relation to casein, and results expressed in percentages. In vitro starch hydrolysis was determined according to LOPES et al. (2012). Starch digestibility was expressed as a percentage of the reducing sugar obtained after hydrolysis, using corn starch as control.

\section{Statistical analysis}

The frequency distribution of the sampling errors is normal, and the variances are homogeneous. Therefore, it was assumed that the data showed parametric distribution and were evaluated by ANOVA, followed by Tukey test (posthoc test, $\mathrm{P}<0.05$ ) using Statsoft (2007). Results were expressed as means followed by standard deviation of three or four replicates.

\section{RESULTS AND DISCUSSION}

\section{Proximate composition}

The chemical composition of the broken rice flour (Table 2) was similar to those reported by NAVES (2007) for lipids $\left(0.36 \mathrm{~g} \cdot 100 \mathrm{~g}^{-1}\right)$ and protein

Ciência Rural, v.50, n.6, 2020. 
$\left(8.27 \mathrm{~g} \cdot 100 \mathrm{~g}^{-1}\right)$, but lower for TDF (1.57 to 3.9 $\left.\mathrm{g} \cdot 100 \mathrm{~g}^{-1}\right)$. Once the lipids are concentrated $(80 \%)$ on the outer layers of the grain (rice bran), the resulted flour grit from polished rice grains is expected to present low lipid content. The same reduction after rice polishing occurs for ashes and TDF which are concentrated on the rice bran (NAVES, 2007). Despite the low-fat content, NAVES (2007) confirmed that polished rice is rich in unsaturated fatty acids oleic (C18:1) and linoleic (C18:2), while the TDF is composed mainly of hemicellulose and pectin. Because of these nutritional characteristics, rice consumption is recommended to maintain a healthy weight and for the prevention and control of chronic diseases (especially obesity, cardiovascular disease, and cancer) (NAVES, 2007).

The amount of RGF carbohydrates in this study was within the range reported in other studies, which ranged from $76 \%$ to $86 \%$ (ASCHIERI et al., 2006). Because it is basically composed of complex carbohydrates, rice is an excellent source of energy and can contribute up to one fifth of the energy intake of a healthy adult (NAVES, 2007). Similarly, WF and
CS are food sources of energy from carbohydrates (Table 2), which presented values close to those reported in the literature $(75 \%$ to $84 \%$ for wheat flour and $87 \%$ for corn starch) (TACO, 2011; WANG et al., 2006). In contrast to these flours, RBF and EBF had significantly lower carbohydrate values, which is to be expected due to higher protein, ash and total dietary fiber contents (GOMES et al., 2006; MARZO et al., 2002).

The lipid content of RBF and EBF corresponded with reported values for raw bean and extruded bean flours (CARVALHO et al., 2012b, MARZO et al., 2002). Extrusion can reduce lipid content by forming a lipid-starch complex, accounting for the significant difference between RBF and EBF (MARZO et al., 2002), thereby providing nutritional benefit. Ash contents of RBF and EBF (Table 2) were within the range reported previously (CARVALHO et al., 2012b, MARZO et al., 2002 GOMES et al., 2006). Ash contents increased linearly $\left(r^{2}=0.91\right)$ with increasing EBF content of the cakes (Figure 1).

The protein contents of RBF and EBF were highest compared to WF, CS and RGF (Table 2). The

Table 2 - Proximate composition (wet basis) of the flours, cake mixes, and cakes ready for consumption $\left(\mathrm{g} \cdot 100 \mathrm{~g}^{-1}\right)^{*}$.

\begin{tabular}{|c|c|c|c|c|c|c|c|c|}
\hline \multirow[t]{2}{*}{ Sample } & \multirow[t]{2}{*}{ Lipids } & \multirow[t]{2}{*}{ Ash } & \multirow[t]{2}{*}{ Protein } & \multicolumn{3}{|c|}{-Dietary fiber- } & \multirow[t]{2}{*}{ Carbohydrates } & \multirow[t]{2}{*}{$\begin{array}{l}\text { Total energy value } \\
\text { (kcal) }\end{array}$} \\
\hline & & & & Total & Soluble & Insoluble & & \\
\hline \multicolumn{9}{|c|}{-Flour-___ } \\
\hline RGF & $0.38 \pm 0.03^{\mathrm{d}}$ & $0.39 \pm 0.00^{\mathrm{d}}$ & $8.04 \pm 0.06^{\mathrm{d}}$ & $0.99 \pm 0.04^{\mathrm{c}}$ & $0.27 \pm 0.01^{\mathrm{d}}$ & $0.72 \pm 0.04^{\mathrm{d}}$ & $81.43 \pm 0.07^{\mathrm{b}}$ & 361.30 \\
\hline $\mathrm{RBF}$ & $1.34 \pm 0.05^{\mathrm{a}}$ & $3.65 \pm 0.01^{\mathrm{b}}$ & $21.53 \pm 0.07^{\mathrm{a}}$ & $19.54 \pm 0.85^{\mathrm{a}}$ & $2.65 \pm 0.35^{\mathrm{b}}$ & $16.89 \pm 0.81^{\mathrm{a}}$ & $45.48 \pm 0.83^{\mathrm{e}}$ & 280.09 \\
\hline $\mathrm{EBF}$ & $0.81 \pm 0.05^{\mathrm{c}}$ & $3.80 \pm 0.04^{\mathrm{a}}$ & $21.35 \pm 0.05^{\mathrm{b}}$ & $19.08 \pm 0.28^{\mathrm{a}}$ & $3.96 \pm 0.01^{\mathrm{a}}$ & $15.12 \pm 0.28^{b}$ & $50.05 \pm 0.28^{d}$ & 292.86 \\
\hline WF & $1.07 \pm 0.11^{\mathrm{b}}$ & $0.56 \pm 0.03^{\mathrm{c}}$ & $13.49 \pm 0.05^{\mathrm{c}}$ & $2.53 \pm 0.22^{b}$ & $1.20 \pm 0.34^{c}$ & $1.34 \pm 0.25^{\mathrm{c}}$ & $71.28 \pm 0.33^{\mathrm{c}}$ & 348.74 \\
\hline CS & ND & $0.06 \pm 0.00^{\mathrm{e}}$ & $0.60 \pm 0.04^{\mathrm{e}}$ & ND & ND & ND & $88.91 \pm 0.15^{\mathrm{a}}$ & 358.04 \\
\hline \multicolumn{9}{|c|}{-Cake mix- } \\
\hline CM45 & $0.16 \pm 0.00^{\mathrm{C}}$ & $2.45 \pm 0.01^{\mathrm{C}}$ & $5.01 \pm 0.09^{\mathrm{C}}$ & - & - & - & $89.35 \pm 0.11^{\mathrm{A}}$ & 378.89 \\
\hline CM60 & $0.20 \pm 0.01^{\mathrm{BC}}$ & $2.93 \pm 0.05^{\mathrm{B}}$ & $6.58 \pm 0.48^{\mathrm{B}}$ & - & - & - & $87.84 \pm 0.46^{\mathrm{B}}$ & 379.45 \\
\hline CM75 & $0.21 \pm 0.03^{\mathrm{B}}$ & $3.39 \pm 0.13^{\mathrm{A}}$ & $7.45 \pm 0.06^{\mathrm{A}}$ & - & - & - & $86.47 \pm 0.09^{C}$ & 377.55 \\
\hline \multicolumn{9}{|c|}{-Cake-_- } \\
\hline WC & $8.38 \pm 0.29^{x}$ & $2.01 \pm 0.10^{y}$ & $9.06 \pm 0.02^{\mathrm{yz}}$ & $1.87 \pm 0.18^{z}$ & $0.32 \pm 0.05^{\mathrm{y}}$ & $1.54 \pm 0.17^{\mathrm{z}}$ & $75.11 \pm 0.26^{x}$ & 412.08 \\
\hline $\mathrm{C} 45$ & $7.67 \pm 0.08^{y}$ & $2.69 \pm 0.00^{\mathrm{x}}$ & $8.94 \pm 0.03^{\mathrm{z}}$ & $4.47 \pm 0.45^{\mathrm{y}}$ & $1.09 \pm 0.20^{x}$ & $3.38 \pm 0.34^{y}$ & $73.20 \pm 0.40^{y}$ & 397.56 \\
\hline C60 & $8.22 \pm 0.20^{\mathrm{x}}$ & $3.45 \pm 0.10^{\mathrm{w}}$ & $9.19 \pm 0.03^{y}$ & $4.79 \pm 0.29^{y}$ & $1.35 \pm 0.32^{\mathrm{x}}$ & $3.45 \pm 0.35^{\mathrm{y}}$ & $69.18 \pm 0.19^{z}$ & 387.48 \\
\hline $\mathrm{C} 75$ & $7.90 \pm 0.04^{\mathrm{xy}}$ & $3.28 \pm 0.01^{\mathrm{w}}$ & $10.28 \pm 0.08^{x}$ & $6.49 \pm 0.37^{x}$ & $1.72 \pm 0.38^{x}$ & $4.77 \pm 0.74^{x}$ & $68.60 \pm 0.66^{z}$ & 386.67 \\
\hline
\end{tabular}

${ }^{*}$ Results are presented as means \pm standard deviation of three replicates, except the four replicates for dietary fibers. Means in a column followed by different letters are significantly different by Tukey's test at the 5\% level. RGF- rice grit flour; RBF- raw bean flour; EBFsplit bean extruded flour; WF- wheat flour; CS- cornstarch; WCM - wheat cake mix - control; CM45, CM60 and CM75 - cake mix with 45, 60 and 75\% EBF, respectively; WC - wheat cake - control; C45 - cake with 45\% EBF; C60 - cake with $60 \%$ EBF; C75 - cake with $75 \%$ EBF. ND: not detected. ${ }^{c}$ Total, soluble and insoluble dietary fibers were not analyzed for the cake mixes, due to cost and because we considered more relevant to evaluate their contents in raw samples (as ingredients) to investigate their influence on the fiber content of ready-to-eat cakes. 
results of this study are in agreement with previous reports of protein content (19-26\%) in raw and extruded bean flours (CARVALHO et al., 2012b, MARZO et al., 2002, GOMES et al., 2006). Furthermore, the gradual addition of EBF increased significantly the protein content of the cake mix (Figure 1), as well as for the cakes. These results are in agreement with various studies demonstrating that products prepared with protein mixtures in appropriate proportions usually meet the protein needs, especially for children and elderly people, as well as specific groups such as celiac patients (CARVALHO et al., 2012a, GOMES et al., 2014, ASCHERI et al., 2006, SOUZA et al., 2013).

A solid food can be considered a fiber source or high content in fibers when it contains at least 3.0 or $6.0 \mathrm{~g} \cdot 100 \mathrm{~g}^{-1}$ of fibers, respectively. In this context, RBF and EBF flours can be classified as high in fiber content, containing higher TDF values compared to the flours (Table 2). The TDF contents in the bean flours (RBF and EBF) were higher than those reported by Ascheri et al., (2006), who also reported no significant differences in TDF between RBF and EBF. Increasing bean flour in cake mixes significantly increased protein, ash, TDF, SDF and IDF content (Table 2, Figures $1 \mathrm{~A}$ and 1B). These results were expected, since EBF presented great protein, ash and dietary fiber content.

Due to unavailable scientific information in the literature, the composition of macronutrients and energy of the cake mix were compared to those of commercial cakes. The gluten-free cake mixes (Table 2) generally had protein values close to or higher than those of commercial mixtures (4.32 to $\left.6.49 \mathrm{~g} \cdot 100 \mathrm{~g}^{-1}\right)$, especially when compared to the gluten-free commercial cake mix $\left(\leq 3.20 \mathrm{~g} \cdot 100 \mathrm{~g}^{-1}\right.$ protein) (label values). In contrast, the cake mixes had lower lipid content than commercial formulations (1.40 to $9.73 \mathrm{~g} \cdot 100 \mathrm{~g}^{-1}$, made with vegetal oil or soy products), and positively influenced the nutritional quality of the products according to low daily lipid intake recommendations. The carbohydrate content, as well as the energy of the cake mixes, had similar values (Table 2) compared to a range of commercial cake mixes ( 83.78 to $88.00 \mathrm{~g} \cdot 100 \mathrm{~g}^{-1}$ and 356.76 to $389.19 \mathrm{kcal})$.

The C75 presented the highest protein content, followed by $\mathrm{C} 60$, WC and C45 (Table 2 ). The protein content of the gluten-free cakes $\left(9.1 \mathrm{~g} \cdot 100 \mathrm{~g}^{-1}\right)$ was similar to those reported for beanenriched gluten-free cakes (GULARTE et al., 2012). The C75 cake with $10.28 \%$ of protein content is a protein source for adults and contains high protein content for 7 to 10 year- children, as it meets the requirements of at least 10 and $20 \%$, respectively, of the IDR reference per $100 \mathrm{~g}$ of food (BRASIL, 2012; BRASIL 2005; IOM, 2002). Lipid, ash, and carbohydrate contents were within the literature range reported for several cake formulations; 2.2 to 16.7 $\mathrm{g} \cdot 100 \mathrm{~g}^{-1}$ for lipids, 1.93 to $5.1 \mathrm{~g} \cdot 100 \mathrm{~g}^{-1}$ for ash, and 51.9 to $74.9 \mathrm{~g} \cdot 100 \mathrm{~g}^{-1}$ for carbohydrates (SOUZA et al., 2013, GULARTE et al., 2012). Analyses of the gluten-free cake formulation $\mathrm{C} 75$, indicated that the use of $\mathrm{RCF}$ and EBF mixtures favors the nutritional quality of the product, as it reduces carbohydrates and increases ash, proteins and dietary fibers contents (Table 2).

C45 and C60 cakes can be considered good sources of TDF and C75 is abundant in TDF,
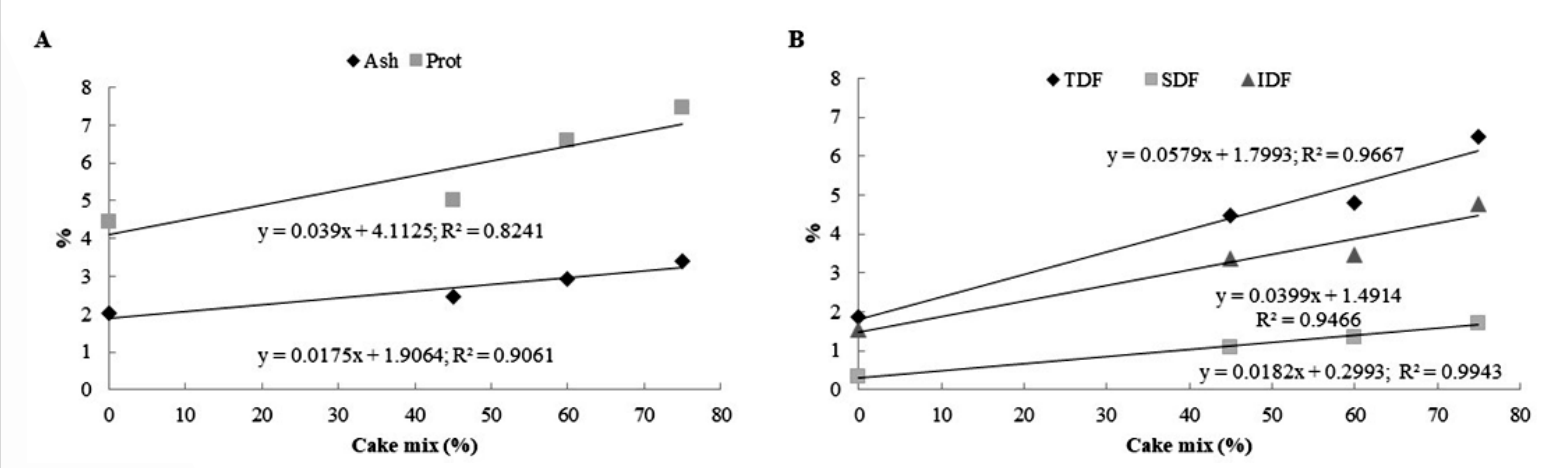

Figure 1 - Protein and ash content profile (A); Fiber fractions profile (total - TDF, soluble - SDF and insoluble - IDF) (B) in rice and bean cakes mixes. 
while WC is not a good source of TDF (BRASIL, 2012). This was due to the replacement of WF by EBF, increasing TDF content 3.5 times (C75), similar to those described by SOUZA et al. (2013) for cakes with $75 \%$ of cassava peel flour, and even superior to the $14 \%$ increase achieved by GULARTE et al. (2012), using $50 \%$ of bean flour when replacing rice flour.

Soluble and insoluble dietary fiber contents (SDF and IDF) followed the same trend as TDF (Table 2). The TDF, SDF, and IDF increased linearly with increased EBF content in the cake mix (Figure 1B). However, the rate of increase was highest for IDF than for SDF, probably because EBF presents high IDF content (Table 2). A portion (50 g) of C75 would contribute to $9.18 \%$ (male) and $11.17 \%$ (female) of the daily protein requirement; $8.54 \%$ (male) and $12.98 \%$ (female) of total dietary fiber; $9.67 \%$ of the calories, and $26.38 \%$ of daily carbohydrates for both adults gender aged 19 - 30 years (IOM, 2002; BRASIL, 2005).

\section{Minerals and vitamins}

The mineral (iron, calcium and zinc) was investigated for RGF, RBF, EBF, WF, CS and the cakes, since theses minerals are important for health and pulses can be a source of that. The calcium content of RGF, WF and CS (Table 3) was higher than those described in TACO, of 4.0; 18.0 and 1.0 mg. $100 \mathrm{~g}^{-1}$, respectively (TACO, 2011), and for RGF, ASCHERI et al. (2006) reported similar value of calcium in rice bran flour $\left(6.49 \mathrm{mg} .100 \mathrm{~g}^{-1}\right)$. For the bean flours, calcium contents of RBF and EBF were within reported values (30 to $240 \mathrm{mg} \cdot 100 \mathrm{~g}^{-1}$ for $\mathrm{RBF}$ and 63 to $123 \mathrm{mg} \cdot 100 \mathrm{~g}^{-1}$ for EBF) (GOMES et al., 2006, NIKMARAM et al., 2017). Calcium is one of the most challenging minerals to reach the recommended daily intake, which validates the use of alternative calcium food sources such as beans, in its traditional form of consumption.

Iron contents of RGF, RBF, and EBF (Table 3) were within the range described in the literature (GOMES et al., 2006). The iron and calcium contents of all flour samples for RBF and EBF were different; daily intake of $100 \mathrm{~g}$ attains $100 \%$ of recommended nutritional iron $(8 \mathrm{mg})$ for men (19 - 30 years) and more than $70 \%$ for women (18 $\mathrm{mg}$ ) of the same age (MARZO et al., 2002), not taking into account iron bioavailability. Iron values obtained for WF and CS are higher than those reported by TACO, which is 1.0 and $0.1 \mathrm{mg} .100 \mathrm{~g}^{-1}$, respectively (TACO, 2011), but still very low, which in wheat flour case justifies the need for a regulatory standard for product fortification with iron.

Zinc contents of RGF, RBF, and EBF (Table 3) were also within the range described in the literature; 1.20 to $2.35 \mathrm{mg} \cdot 100 \mathrm{~g}^{-1}$ for rice flours, 2.23 to $6.39 \mathrm{mg} \cdot 100 \mathrm{~g}^{-1}$ for raw bean flours and 2.27 to 3.20 $\mathrm{mg} \cdot 100 \mathrm{~g}^{-1}$ for extruded bean flour (GOMES et al., 2006). The zinc values obtained for WF and CS are higher and equal to those reported by TACO, which is 0.8 and 0.1 $\mathrm{mg} 100 \mathrm{~g}^{-1}$, respectively (TACO, 2011). Zinc is essential in several metabolic pathways, and its deficiency causes increased susceptibility to infections, delays in growth and reproductive problems.

In resume, the extrusion processes improve the mineral content of the split bean; and the beans flour present a high content of minerals compared with WF, RGF and CS. So, the cakes made with more EBF, presented the highest content of minerals.

Thiamine and riboflavin contents of RGF (Table 5) were similar to previous reports (GOMES

Table 3 - Mineral and vitamin contents (wet basis) of flours and the cakes $\left(\mathrm{mg} \cdot 100 \mathrm{~g}^{-1}\right)^{1}$.

\begin{tabular}{lccccc}
\hline Sample $^{2}$ & Calcium & Iron & Zinc & Thiamine (B1) & Riboflavin(B2) \\
\hline RGF & $6.55 \pm 0.01 \mathrm{~d}$ & $2.56 \pm 0.17 \mathrm{c}$ & $1.59 \pm 0.23 \mathrm{c}$ & $0.06 \pm 0.00 \mathrm{c}$ & $0.04 \pm 0.00 \mathrm{~d}$ \\
RBF & $75.08 \pm 0.02 \mathrm{~b}$ & $12.74 \pm 5.34 \mathrm{~b}$ & $2.47 \pm 0.87 \mathrm{~b}$ & $0.25 \pm 0.01 \mathrm{a}$ & $0.09 \pm 0.00 \mathrm{a}$ \\
EBF & $83.28 \pm 0.01 \mathrm{a}$ & $14.73 \pm 2.34 \mathrm{a}$ & $2.63 \pm 0.26 \mathrm{a}$ & $0.24 \pm 0.01 \mathrm{a}$ & $0.07 \pm 0.00 \mathrm{~b}$ \\
WF & $22.42 \pm 0.01 \mathrm{c}$ & $1.44 \pm 1.09 \mathrm{~d}$ & $1.40 \pm 0.72 \mathrm{~d}$ & $0.18 \pm 0.00 \mathrm{~b}$ & $0.05 \pm 0.00 \mathrm{c}$ \\
CS & $1.46 \pm 0.01 \mathrm{e}$ & $0.29 \pm 0.17 \mathrm{e}$ & $0.10 \pm 0.16 \mathrm{e}$ & $0.01 \pm 0.00 \mathrm{~d}$ & $0.02 \pm 0.00 \mathrm{e}$ \\
WC & $94.71 \pm 0.03^{\mathrm{B}}$ & $1.12 \pm 0.25^{\mathrm{C}}$ & $1.02 \pm 0.07^{\mathrm{C}}$ & $0.03 \pm 0.00^{\mathrm{C}}$ & $0.09 \pm 0.00^{\mathrm{C}}$ \\
C45 & $108.63 \pm 0.06^{\mathrm{A}, \mathrm{B}}$ & $2.61 \pm 0.99^{\mathrm{B}}$ & $1.16 \pm 0.13^{\mathrm{B}}$ & $0.04 \pm 0.00^{\mathrm{B}}$ & $0.13 \pm 0.00^{\mathrm{B}}$ \\
C75 & $123.39 \pm 0.08^{\mathrm{A}}$ & $3.91 \pm 0.67^{\mathrm{A}}$ & $1.25 \pm 0.17^{\mathrm{A}}$ & $0.06 \pm 0.00^{\mathrm{A}}$ & $0.14 \pm 0.00^{\mathrm{A}}$ \\
\hline
\end{tabular}

${ }^{1}$ Results are presented as means \pm standard deviation of three replicates. Means in a column followed by different letters are significantly different by Tukey's test at the 5\% level. ${ }^{2}$ RGF- rice grit flour; RBF- raw bean flour; EBF- split been extruded flour; WF- wheat flour; CS- cornstarch; WC - wheat cake - control; C45 - cake with 45\% EBF; C75 - cake with $75 \%$ EBF. 
et al., 2014a). For RBF and EBF, thiamine values remained within the range described in the literature for raw bean flour $\left(0.17\right.$ to $\left.0.45 \mathrm{mg} \cdot 100 \mathrm{~g}^{-1}\right)$, and were lower for riboflavin content $\left(0.15 \mathrm{mg} \cdot 100 \mathrm{~g}^{-1}\right)$ (GOMES et al., 2014a), with no significant difference between them, but with higher values $(\mathrm{P}<0.05)$ compared to other flours.

Mineral and vitamin contents increased significantly $(\mathrm{P}<0.05)$ with replacement of WF by the RCF and EBF mixtures (Table 3). The contents of calcium, iron, zinc and vitamin presented by $\mathrm{C} 75$ were significantly higher than those presented by $\mathrm{WC}$ and $\mathrm{C} 45$, and consistent with results obtained for flours as raw materials. Eating a slice of C75 (50 g) can contribute to the nutritional recommendations: $6.17 \%$ for calcium; $24.44 \%$ (men) and $10.86 \%$ (women) for iron; 5.68\% (men) and 7.81\% (women) for zinc; $2.61 \%$ thiamine and $5.38 \%$ (men) and $6.36 \%$ (women) for riboflavin (IOM, 2001; IOM, 1998) for 19 to 30 years old adults. According to Brazilian regimentation, a slice of $\mathrm{C} 75$ can contribute with $6.17 \%$ for calcium, $13.96 \%$ for iron and $8.93 \%$ for zinc for adults (BRASIL, 2005).

\section{Phytic acid and tannin contents}

Phytic acid contents of RBF and EBF (Table 4) were lower than those in cereals such as maize, millet, oats and whole wheat (FUKUJI et al., 2008), and within the range reported in the literature (BATISTA et al., 2010, BRIAN et al., 1984). Reduction in phytic acid was insignificant between RBF and EBF, unlike other studies that showed a significant reduction from $12.6 \%$ to $26 \%$ in the phytic acid content of extruded beans (CARVALHO et al., 2012b, NIKMARAM et al., 2017). Probably due to the lower extrusion temperature $\left(70{ }^{\circ} \mathrm{C}\right.$ vs. $\left.150{ }^{\circ} \mathrm{C}\right)$ used in this study, indicating that higher temperature hydrolyzes phytic acid, thereby hampering their detection (CARVALHO et al., 2012b). Conversely, oven baked $\left(180{ }^{\circ} \mathrm{C}\right)$ cakes showed considerable $(80 \%)$ decrease in phytic acid relative to EBF. This reduction corresponds to those detected in the preparation of snacks $(60 \%$ to $90 \%)$, containing about $25 \%$ bean flour, and cookies containing up to $30 \%$ pre-gelatinized rice and bean flour (CARVALHO et al., 2012a, BERRIOS et al., 2013). Even though the cooking process of the cakes did not wholly eliminate phytic acid, its content was lower than similar products prepared with different cereals. For the food industry, some studies have shown that this compound could improve the nutritional quality, prevent discoloration and prolong product shelf-life (FUKUJI et al., 2008).

Tannin contents of RBF and EBF (Table 4) were higher than in most of the surveyed literature, ranging from 0.97 to $2.33 \mathrm{mg} \cdot \mathrm{g}^{-1}$ (MARZO et al., 2002), except for a similar reported value in another study (4.61 $\left.\mathrm{mg} \cdot \mathrm{g}^{-1}\right)$ (GOMES et al., 2014a). Differences could be due to the chemical composition of bean varieties, processing methods, analytical methodologies, and the hull proportion in the sample (CARVALHO et al., 2012a). Temperature is an essential parameter for determining the thermal degradation of these compounds, as well as inducing changes in its chemical reactivity and solubility, or the formation of insoluble complexes. This helps explain the significant tannin reduction from RBF to EBF (average $46 \%$ ), using a lower temperature $\left(70{ }^{\circ} \mathrm{C}\right)$ than other investigators (average $80 \%$ reduction), with

Table 4 - Phytic acid and tannin content $\left(\mathrm{mg} \cdot \mathrm{g}^{-1}\right.$ flour) and starch and protein digestibility values (\%) of flours and ready-to-eat cakes ${ }^{1}$

\begin{tabular}{lcccr}
\hline Sample $^{2}$ & Phytic Acid & Tannins & Protein digestibility & Starch digestibility \\
\hline RGF & - & - & $28.19 \pm 0.12 \mathrm{~b}$ & $97.07 \pm 5.94^{\mathrm{a}}$ \\
RBF & $5.7 \pm 0.02$ & $5.56 \pm 1.09 \mathrm{a}$ & $34.69 \pm 0.38 \mathrm{~b}$ & $26.21 \pm 3.20 \mathrm{~d}$ \\
EBF & $5.4 \pm 0.02$ & $3.02 \pm 0.13 \mathrm{~b}$ & $50.67 \pm 0.42 \mathrm{a}$ & $41.89 \pm 2.92 \mathrm{c}$ \\
WF & - & - & $34.52 \pm 0.34 \mathrm{~b}$ & $61.75 \pm 4.23 \mathrm{~b}$ \\
CS & - & - & $6.77 \pm 0.08 \mathrm{c}$ & $100.00 \pm 2.77 \mathrm{a}$ \\
WC & - & - & $28.54 \pm 0.07^{\mathrm{B}}$ & $53.45 \pm 3.61^{\mathrm{A}}$ \\
C45 & $0.9 \pm 0.01^{\mathrm{C}}$ & ND & $27.09 \pm 0.34^{\mathrm{B}}$ & $59.03 \pm 4.33^{\mathrm{A}}$ \\
C60 & $1.1 \pm 0.00^{\mathrm{B}}$ & ND & $31.36 \pm 0.09^{\mathrm{A}, \mathrm{B}}$ & $47.24 \pm 0.00^{\mathrm{B}}$ \\
C75 & $1.4 \pm 0.00^{\mathrm{A}}$ & ND & $33.97 \pm 0.05^{\mathrm{A}}$ & $48.33 \pm 1.02^{\mathrm{B}}$ \\
\end{tabular}

${ }^{1}$ Results are presented as means \pm standard deviation of three replicates. Means in a column followed by different letters are significantly different by Tukey's test at the 5\% level. ${ }^{2}$ RGF- rice grit flour; RBF- raw bean flour; EBF- split been extruded flour; WF- wheat flour; CS- cornstarch; WC - wheat cake - control; C45, C60 and C75 - cake with 45, 60 and 75\% EBF, respectively. 
extruding temperatures above $150{ }^{\circ} \mathrm{C}$ (CARVALHO et al., 2012a, MARZO et al., 2002). In ready-to-eat cakes, tannins were undetected (Table 4); consistent with similar studies in the preparation of cookies (CARVALHO et al., 2012a).

\section{Amino acids profile}

The amino acid profile was determined for flours and for the cakes WC, C45 and C75. The amino acid profile of cake $\mathrm{C} 60$ was not determined, since it presented low sensory acceptance reported previously (GOMES et al., 2014a). The amino acid profile of RGF (Table 5) was similar to those reported previously (GOMES et al., 2014a) with lysine as the limiting amino acid. Lysine was also the limiting amino acid for WF in this study and PIRES et al. (2006), demonstrating that lysine is the limiting amino acid of cereal proteins. For RBF and EBF, isoleucine, histidine, leucine, phenylalanine-tyrosine, valine and threonine values were within the ranges reported in the literature, both for raw and extruded beans (GOMES et al., 2014a, MARZO et al., 2002, PIRES et al., 2006).
The sulfur amino acids were limiting for their protein quality (EAS $=0.75$ and 0.69 , respectively), with average values higher than those reported by CARVALHO et al. (2012b) and MARZO et al. (2002) (10.6 to $14.1 \mathrm{mg} \cdot \mathrm{g}^{-1}$ protein), and similar to those found by PIRES et al. (2006) (19.95 $\mathrm{mg} \cdot \mathrm{g}^{-1}$ protein).

$\mathrm{RBF}$ and EBF flours had similar lysine content in contrast to the lysine reduction reported after bean extrusion (BATISTA et al., 2010). The lysine content (Table 5) was 2.13 times higher in bean flours (RBF and EBF) than in the RGF, on the average, resembling the increase of 2.6 times described in another study with rice grit flour and split bean flour (GOMES et al., 2014a). In contrast, the sulfur amino acid contents of the RGF was 2.19 times higher than those in the split bean flour, and 2.7 times higher than reported in earlier studies (GOMES et al., 2014a), demonstrating that beans can complement rice that is deficient in lysine and relatively rich in sulfur amino acids. NAVES (2007) also reported that the combination of rice and beans results in good protein quality, fulfilling $93 \%$ of the needs of children in preschool age.

Table 5 - Composition of essential amino acids $\left(\mathrm{mg} \cdot \mathrm{g}^{-1} \text { of protein }\right)^{1}$ of flours and ready-to-eat cakes.

\begin{tabular}{|c|c|c|c|c|c|}
\hline Flours & RGF & $\mathrm{RBF}$ & $\mathrm{EBF}$ & WF & Standard $^{2}$ \\
\hline Met-Cyst ${ }^{c}$ & $37.77 \pm 9.28 \mathrm{a}$ & $18.00 \pm 1.58 \mathrm{~b}$ & $16.46 \pm 0.11 b$ & $19.14 \pm 1.35 \mathrm{a}, \mathrm{b}$ & 26.0 \\
\hline Isoleucine & $38.25 \pm 6.80 \mathrm{a}$ & $41.11 \pm 4.97 \mathrm{a}$ & $42.47 \pm 2.06 a$ & $33.32 \pm 2.64 a$ & 31.0 \\
\hline Histidine & $20.63 \pm 3.78 \mathrm{a}$ & $32.26 \pm 4.24 \mathrm{a}$ & $33.88 \pm 0.40 \mathrm{a}$ & $25.09 \pm 6.93 \mathrm{a}$ & 18.0 \\
\hline Leucine & $78.88 \pm 3.98 \mathrm{a}$ & $80.52 \pm 3.46 a$ & $79.09 \pm 4.24 \mathrm{a}$ & $64.64 \pm 1.03 b$ & 63.0 \\
\hline Phenyl-Tyr ${ }^{\mathrm{d}}$ & $93.55 \pm 4.21 b$ & $106.89 \pm 2.41 \mathrm{a}$ & $109.45 \pm 0.96 a$ & $76.77 \pm 2.25 c$ & 46.0 \\
\hline Lysine & $47.22 \pm 0.94 b$ & $101.60 \pm 1.25 \mathrm{a}$ & $99.14 \pm 1.97 \mathrm{a}$ & $24.89 \pm 3.12 c$ & 52.0 \\
\hline Valine & $55.35 \pm 6.83 a$ & $52.85 \pm 5.46 \mathrm{a}$ & $52.50 \pm 1.48 \mathrm{a}$ & $39.73 \pm 1.80 \mathrm{a}$ & 42.0 \\
\hline Threonine & $34.44 \pm 4.62 b, c$ & $44.40 \pm 1.67 \mathrm{a}, \mathrm{b}$ & $47.21 \pm 1.20 \mathrm{a}$ & $27.76 \pm 0.61 \mathrm{c}$ & 27.0 \\
\hline Total & 406.09 & 477.63 & 480.20 & 311.34 & 305.00 \\
\hline EAS & 0.98 & 0.75 & 0.69 & 0.52 & \\
\hline Cakes & WC & $\mathrm{C} 45$ & $\mathrm{C} 75$ & & Standard $^{2}$ \\
\hline Met-Cyst ${ }^{3}$ & $34.92 \pm 0.10^{\mathrm{A}}$ & $32.82 \pm 1.42^{\mathrm{A}}$ & $27.97 \pm 0.09^{B}$ & & 26.0 \\
\hline Isoleucine & $39.81 \pm 6.05^{\mathrm{A}}$ & $41.88 \pm 0.93^{\mathrm{A}}$ & $49.03 \pm 0.42^{\mathrm{A}}$ & & 31.0 \\
\hline Histidine & $29.59 \pm 10.79^{A}$ & $33.83 \pm 2.71^{\mathrm{A}}$ & $27.93 \pm 2.75^{\mathrm{A}}$ & & 18.0 \\
\hline Leucine & $76.07 \pm 4.19^{\mathrm{A}}$ & $78.67 \pm 3.17^{\mathrm{A}}$ & $85.47 \pm 0.40^{\mathrm{A}}$ & & 63.0 \\
\hline Phenyl-Tyr ${ }^{4}$ & $99.36 \pm 2.98^{\mathrm{A}}$ & $95.62 \pm 4.40^{\mathrm{A}}$ & $104.20 \pm 1.68^{\mathrm{A}}$ & & 46.0 \\
\hline Lysine & $59.17 \pm 5.85^{B}$ & $82.14 \pm 2.53^{\mathrm{A}}$ & $94.64 \pm 1.23^{\mathrm{A}}$ & & 52.0 \\
\hline Valine & $56.57 \pm 0.36^{\mathrm{B}}$ & $55.71 \pm 0.66^{\mathrm{B}}$ & $62.35 \pm 1.12^{\mathrm{A}}$ & & 42.0 \\
\hline Threonine & $39.00 \pm 3.69^{A}$ & $49.41 \pm 0.26^{\mathrm{A}}$ & $41.53 \pm 2.69^{\mathrm{A}}$ & & 27.0 \\
\hline Total & 434.49 & 470.08 & 493.12 & & 305.00 \\
\hline EAS & 1.14 & 1.25 & 1.08 & & \\
\hline
\end{tabular}

${ }^{1}$ Results are presented as means \pm standard deviation of three replicates. Means in a column followed by different letters are significantly different by Tukey's test at the 5\% level. RGF- rice grit flour; RBF- raw bean flour; EBF- split been extruded flour; WF- wheat flour; CS- cornstarch; WC - wheat cake - control; C45 - cake with 45\% EBF; C75 - cake with 75\% EBF. ${ }^{2} \mathrm{FAO} / \mathrm{WHO} / \mathrm{UNU}$ standard for preschool children from 1 to 2 years old (WHO, 2007). ${ }^{\mathrm{c}}$ Met-Cist: methionine and cysteine - sulfur amino acids; ${ }^{\mathrm{d}}$ Phenyl-Tyr: phenylalanine and tyrosine. Values in bold are the limiting essential amino acids in each sample. 


\section{Protein and starch digestibility}

The processing of the bean flour by extrusion significantly increased EBF's protein $(46 \%)$ and starch $(60 \%)$ digestibility (Table 4$)$. The combination of temperature, moisture, and shear stress during the extrusion process denatured and aggregated the proteins and gelatinized the starch, increasing digestibility (SOUZA et al., 2013, PIRES et al., 2006). The thermal treatment employed during extrusion often leads to inactivation of trypsin inhibitors, which normally improve protein digestibility. In addition, exposition of a higher number of protein linkages to enzymatic hydrolysis due to protein denaturation is another expected result of extrusion. A similar increase in protein digestibility in vitro has been reported for extruded bean flour (FAROOQ \& BOYE, 2011; LOPES et al., 2012).

The increase of in vitro starch digestibility of EBF was expected as the extruded process opens the starch grain and increases the accessibility of enzymes responsible for starch hydrolysis (LOPES et al., 2012). The WF and CS presented the highest starch digestibility. This was expected too, since starch digestibility depends on the amount of starch susceptible to $\alpha$-amylase and amyloglucosidase action, as well as on the structural characteristics of starch grain. For the cakes, protein digestibility increased with increasing EBF concentration. Conversely, no statistical difference $(\mathrm{P}>0.05)$ was observed for starch digestibility when comparing rice-bean cakes (C45) and control (WC) (Table 4). However, with increasing amount of EBF (C60 and C75) the starch digestibility was similar to EBF's digestibility, as expected. Low starch digestibility presented by $\mathrm{C} 60$ and $\mathrm{C} 75$ can be advantageous since it might assist in reducing the glycemic rate of cake.

The present study demonstrates the nutritional benefits (higher protein content, quality and in vitro digestibility; higher dietary fiber [total, soluble and insoluble] and mineral contents) of these gluten-free cakes compared to the control. These findings are in line with the current market standpoint, where beans will continue to grow in relevance and appeal because of their natural health and nutritional benefits. Furthermore, the blends with rice grits have a higher potential for allergic food consumers, in addition to providing the whole amino acid profile.

\section{CONCLUSION}

The incorporation of extruded bean flour in gluten-free cake mix improves protein digestibility and total dietary fiber, besides increasing ash, iron, and zinc contents. In combination with rice grit flour, it enables the preparation of a cake mix with gluten-free protein, resulting in higher nutritional quality, without limiting the amino acids content. The bean flour extrusion process is effective in reducing tannin content and increase in vitro protein and starch digestibility. The cakes, containing up to $75 \%$ of extruded bean flour, presented a high nutritional value, since they had high levels of protein, fiber, minerals and good protein digestibility. Moreover, the cakes produced may have food fiber-rich claims. The use of flours from broken rice and split beans grains by bakery industries are a cost-benefit alternative for the recovery of industrial by products of low commercial value and for wheat flour importing countries.

\section{ACKNOWLEDGEMENTS}

The authors thank the Coordenação de Aperfeiçoamento de Pessoal de Nível Superior (CAPES) for their scholarship support and Embrapa for the research financial of the project ParPerfeito approved at the Call 01/2008 - Macroprograma 3 - code 03.08.01.002.00.00.

\section{DECLARATION OF CONFLICT OF INTERESTS}

The authors declare no conflict of interests. The founding sponsors had no role in the design of the study; in the collection, analyses, or interpretation of data; in the writing of the manuscript; and in the decision to publish the results.

\section{AUTHORS' CONTRIBUTIONS}

All authors contributed equally for the conception and writing of the manuscript. All authors critically revised the manuscript and approved of the final version.

\section{REFERENCES}

AKESON, W. R.; STAHMANN, M. A. A. A pepsin pancreatin digest index of protein quality evaluation. Journal of Nutrition, v.83, p.257-261, 1964. Available from: <https://academic.oup. com/jn/article-abstract/83/3/257/4777852? redirectedFrom=PDF>. Accessed: Mar. 18, 2018. doi: 10.1093/jn/83.3.257.

AOAC (2005) Association of Official Analytical Chemists. Official methods of analysis, 18th edn. AOAC, Gaithersburg.

ASCHERI, D. P. R., et al. Characterization of jaboticaba bagasse flour and functional properties of extrudates. Food Science and Technology, v.26, p.897-905, 2006. Available from: $<$ http://dx.doi. org/10.1590/S0101-20612006000400029>. Accessed: Mar. 12, 2018. doi: 10.1590/S0101-20612006000400029.

BASSINELLO, P. Z., et al. Characterization of cookies formulated with rice and black bean extruded flours. Procedia Food Science, v.1, p.1645-1652, 2011. Available from: <http://dx.doi. org/10.1016/j.profoo.2011.09.243>. Accessed: Mar. 11, 2018. doi: 10.1016/j.profoo.2011.09.243. 
BATISTA, K. A., et al. Changes in the functional properties and antinutritional factors of the extruded hard-to-cook common beans (Phaseolus vulgaris, L.). Journal of Food Science, v.75, p.286-290, 2010. Available from: <http://dx.doi.org/10.1111 /j.1750-3841.2010.01557>. Accessed: Jan. 11, 2018. doi: 10.1111/ j.1750-3841.2010.01557.

BERRIOS, J. D. J. et al. Extrusion processing of dry beans and pulses. In: SIDDIQ, M.; UEBERSAX, M. A. (eds) Dry Beans and Pulses Production, Processing and Nutrition, John Wiley \& Sons, Inc. New York, p.185-203, 2013.

BRASIL. Ministério da Saúde. Agência Nacional de Vigilância Sanitária. Resolução RDC $\mathrm{n}^{\circ}$ 54, de 12 de novembro de 2012. Dispõe sobre o Regulamento Técnico sobre informação nutricional complementar. Diário Oficial da União, 2012. Available from: $<$ http://portal.anvisa.gov.br/documents/\%20 33880/2568070/rdc0054 12 11 2012.pdf/c5ac23fd-974e-4f2c9fbc-48f7e0a31864/>. Accessed: Dec. 14, 2019.

BRASIL. Agência Nacional de Vigilância Sanitária. Resolução RDC, n. 269 de 22 de setembro de 2005. Aprova o regulamento técnico sobre a ingestão diária recomendada (IDR) de proteína, vitaminas e minerais. Diário Oficial da União, 2005. Available from: $<$ http://portal.anvisa.gov. br/documents/33916/394219/RDC_269_2005.pdf/2e95553c-a482-45c3bdd1-f96162d607b3>. Accessed: Dec. 14, 2019.

BRIAN, A., et al. Rapid analysis of amino acids using pre-column derivatization. Journal of Chromatography Biomedicine Science Apply, v.336, p.3-104, 1984. Available from: <http:// dx.doi.org/10.1016/S0378-4347(00)85133-6>. Accessed: Jan. 19, 2018. doi: $10.1016 / \mathrm{S} 0378-4347(00) 85133-6$.

CARVALHO, A. V. et al. Processing and characterization of an extruded snack made from broken rice flour and broken common bean flour. Brazilian Journal of Food Technology, v.15, p.7283, 2012a. Available from: <http://dx.doi.org/10.1590/S1987232012000100008>. Accessed: Jan. 19, 2019. doi: 10.1590 S1981-67232012000100008.

CARVALHO, A. V. et al. Effect of the thermoplastic extrusion parameters on the technological properties of pre-cooked flours prepared with rice and beans. Brazilian Journal of Food Technology, v.15, p.333-342, 2012b. Available from: <http:// dx.doi.org/10.1590/S1981-67232012005000029>. Accessed: Jan. 19, 2019. doi: 10.1590/S1981-67232012005000029.

DE PASQUALE, I. et al. Nutritional and functional effects of the lactic acid bacteria fermentation on gelatinized legume flours. International Journal of Food Microbiology, v.316, n.108426, 2020. Available from: <http://www.sciencedirect.com/science/ article/pii/S0168160519303575>. Accessed: Dec. 19, 2019. doi: 10.1016/j.ijfoodmicro.2019.108426.

EUROPEAN COMMITTEE FOR STANDARDIZATION. European Standard EN 14152: 2003-10. Lebensmittel - Bestimmung von Vitamin B2 mit HPLC. Food stuffs: Determination of vitamin B2 by HPLC, English version of DIN EN 14152. Berlin, 2003.

FAROOQ, Z.; BOYE, J. I. Novel food and industrial applications of pulse flours and fractions. In: TIWARI, B.K. et al. (eds) Pulse Foods: Processing, Quality, and Nutraceutical Applications. Elsevier Inc., Amsterdam, pp 283-323, 2011.

FUKUJI, T. S. et al. Phytic acid in corn hybrids and in some industrialized corn products. Acta Scientarium Agronomy, v.30, p.31-35, 2008. Available from: <http://dx.doi.org/10.4025/ actasciagron.v30i1.1125>. Accessed: Jan. 9, 2019. doi: 10.4025/ actasciagron.v30i1.1125.

GOMES, J. C. et al. (2006) Development and characterization of common bean flour. Revista Ceres, v.53, p.548-558, 2006. Available from: <http://www.ceres.ufv.br/ojs/index.php/ceres/ article/view/3180>. Accessed: Jan. 9, 2019.

GOMES, L. O. F. et al. Application of extruded split beanflour for formulation of gluten-free cake blends. Food Science and Technology, v.35, p.307-313, 2014a. Available from: <http:// dx.doi.org/10.1590/1678-457X.6521>. Accessed: Jan. 29, 2019. doi: 10.1590/1678-457X.6521.

GOMES, L.O.F. et al. Microbiological and physicochemical stability of gluten-free cake mixtures and quality of ready cakes for consumption. Brazilian Journal of Food and Technology, v.17, p.283-295, 2014b. Available from: <http://dx.doi. org/10.1590/1981-6723.0914>. Accessed: Jan. 12, 2019. doi: 10.1590/1981-6723.0914

GULARTE, M. A. et al. Impact of legume flours on quality and in vitro digestibility of starch and protein from gluten-free cakes. Food Bioprocess Technology, v.5, p.3142-3150, 2012. Available from: <http://dx.doi.org/10.1007/s11947-011-0642-3>. Accessed: Jan. 22, 2018. doi: 10.1007/s11947-011-0642-3.

HAGERMAN, A. E.; BUTLER, L. G. Protein precipitation method for the quantitative determination of tannins. Journal Agriculture Food Chemistry, v.26, p.809-812, 1978. Available from: <http:// dx.doi.org/10.1021/jf60218a027>. Accessed: Sep. 22, 2018. doi: $10.1021 / \mathrm{jf} 60218 \mathrm{a} 027$

HAUG, W.; LANTZSCH, H. J. Sensitive method for the rapid determination of phytate in cereals and cereal products. Journal Science Food and Agriculture, v.34, p.1423-1426, 1983. Available from: <http://dx.doi.org/10.1002/jsfa.2740341217>. Accessed: Sep. 12, 2018. doi: 10.1002/jsfa.2740341217.

IOM - Institute of Medicine. Dietary reference intakes for thiamin, riboflavin, niacin, vitamin B6, folate, vitamin B12, pantothenic acid, biotin, and choline. Washington: The National Academies Press, 1998.

IOM - Institute of Medicine. Dietary reference intakes for vitamin $\mathrm{A}$, vitamin $\mathrm{K}$, arsenic, boron, chromium, copper, iodine, iron, manganese, molybdenum, nickel, silicon, vanadium, and zinc. Washington: The National Academies Press, 2001.

IOM - Institute of Medicine. Dietary reference intakes for energy, carbohydrate, fiber, fat, fatty acids, cholesterol, protein and amino acids. Washington: The National Academies Press, 2002.

KAUR, A. et al. Effect of guar gum and xanthan gum on pasting and noodle-making properties of potato, corn, and mung bean starches. Journal of Food Science and Technology, v.52, p.8113-8121, 2012. Available from: <http://dx.doi.org/10.1007/ s13197-015-1954-5>. Accessed: Sep. 12, 2018. doi: 10.1007/ s13197-015-1954-5.

KIEWLICZ, J. et al. Minerals and their bioavailability in relation to dietary fiber, phytates and tannins from gluten and gluten-free flakes. Food Chemistry, v.305, n.125452, 2020. Available from: <http:// www.sciencedirect.com/science/article/pii/S0308814619315675>. Accessed: Dec. 22, 2019. doi: 10.1016/j.foodchem.2019.125452. 
LAMBERT, K.; FICKEN, C. Cost and affordability of a nutritionally balanced gluten-free diet: Is following a gluten- free diet affordable? Nutrition \& Dietetics, v.73, p.36-42, 2016. Available from: <http://dx.doi.org/10.1111/1747-0080.12171>. Accessed: Nov. 26, 2019. doi: 10.1111/1747-0080.12171.

LIMA, S. L. S. et al. Whole flour and protein hydrolysate from common beans reduce the inflammation in BALB/c mice fed with high fat high cholesterol diet. Food research international, v.122, p.330-339, 2019. Available from: <http://www.sciencedirect.com/ science/article/pii/S0963996919302340>. Accessed: Dec. 22, 2019. doi: 10.1016/j.foodres.2019.04.013.

LOPES, L. C. M. et al. Functional, biochemical and pasting properties of extruded bean (Phaseolus vulgaris) cotyledons International Journal of Food Science and Technology, v.47, p.1859-1865, 2012. Available from: <http://dx.doi.org/10.11 11/j.1365-2621.2012.03042.x>. Accessed: Sep. 2, 2018. doi: 10.1111/j.1365-2621.2012.03042.x.

MARZO, F. et al. Nutritional quality of extruded kidney bean (Phaseolus vulgaris L. var. Pinto) and its effects on growth and skeletal muscle nitrogen fractions in rats. Journal of Animal Science, v.80, p.875-879, 2002. Available from: <https://www. ncbi.nlm.nih.gov/pubmed/12002323>. Accessed: Sep. 2, 2018. doi: $10.2527 / 2002.804875 x$.

MERRIL, A. L.; WATT, B. K. Energy value of foods: basis and derivation. Agriculture Handbook $\mathrm{N}^{\circ} 74$, Washington DC: United States Department of Agriculture, 1973.

NAVES, M. M. V. Chemical and nutritive characteristics of rice Boletim do Centro de Pesquisa e Processamento de Alimentos, v.25, p.55-60, 2007. Available from: <http://dx.doi.org/10.5380/ cep.v25i1.8394>. Accessed: Oct. 15, 2018. doi: 10.5380/cep. v25i1.8394.

Nielsen's Global Health and Ingredient - Sentiment Survey of consumers in 63 countries. What's in our food and on our mind: Ingredient and dining-out trends around the world, August 2016, The Nielsen Company, p.29, 2016. Available from $<$ http://www.nielsen.com/us/en/insights/reports/2016/whats-inour-food-and-on-our-minds.html>. Accessed: Oct. 15, 2018.
NIKMARAM, N. et al. Effect of extrusion on the anti-nutritional factors of food products: An overview. Food Control, v.79, p.6273, 2017. Available from: <http://www.sciencedirect.com/science/ article/pii/S0956713517301482>. Accessed: Dec. 23, 2019. doi: 10.1016/j.foodcont.2017.03.027.

NOGUEIRA, A. R. A.; SOUZA, G. B. Manual de laboratório: solo, água, nutrição vegetal, nutrição animal e Alimentos. Embrapa Pecuária Sudeste. São Carlos - SP, 2005.

PIRES, C. V. et al. Nutritional quality and chemical score of amino acids from different protein. Food Science and Technology, v.26, p.179-187, 2006. Available from: <http://dx.doi.org/10.1590/ S0101-20612006000100029>. Accessed: Oct. 15, 2018. doi: 10.1590/S0101-20612006000100029.

SHEVKANI, K.; SINGH, N. Influence of kidney bean, field pea and amaranth protein isolates on the characteristics of starch based gluten free muffins. International Journal of Food Science and Technology, v.49, p.2237-2244, 2014. Available from: <https:// onlinelibrary.wiley.com/doi/abs/10.1111/ijfs.12537>. Accessed: Oct. 15, 2018. doi: 10.1111/ijfs. 12537 .

SOUZA, T. A. C. et al. Gluten-free cakes made with broken rice and cassava peel. Semina Ciência Agrárias, v.34, p.717728, 2013. Available from: <http://dx.doi.org/10.5433/16790359.2013v34n2p717>. Accessed: Nov. 5, 2018. doi: 10.5433/1679-0359.2013v34n2p717.

STATSOFT. STATISTICA 7.0 for Windows Computer program manual. Tulsa: Statsoft, Inc. CD Room, 2007.

TACO - Tabela brasileira de composição dos alimentos. 4. ed. Campinas: UNIVERSIDADE ESTADUAL DE CAMPINAS - UNICAMP; NEPA, 2011. Available from: <http://www.nepa. unicamp.br/taco/tabela.php?ativo=tabela $>$. Accessed: Dec. 5, 2019.

WANG, S. H. et al. Water absorption and sparkling properties of extruded wheat and soybean flours. Ciência e Tecnologia de Alimentos, v.26, p.475-481, 2006. Available from: <http://dx.doi. org/10.1590/S0101-20612006000200035>. Accessed: Dec. 5, 2019. doi: 10.1590/S0101-20612006000200035. 